\title{
Ketidakamanan pekerjaan dan kinerja tugas: Burnout sebagai mediator
}

\author{
Alice Salendu ${ }^{1}$ dan Muhamad Fachri Maldini ${ }^{2}$
}

\begin{abstract}
An increasingly dynamic and uncertain job demands provided new challenges for employees in task performance, had impact on job insecurity, and triggered burnout for employees. This study investigated the predictor role of job insecurity on task performance through mediation role of burnout. Researcher conducted correlational research with non-experimental research design. Data were collected from 106 respondents who were private employees with minimum of one year work experience. The sampling technique used was convenience sampling. This study was conducted by using Job Insecurity Scale, Task Performance Scale, and Maslach Burnout Inventory - General Scale which was adapted in Indonesia language. The data were processed using multiple regression analysis with mediating variable. The result of this research showed that job insecurity had negative relationship with task performance $(b=-0.35, t=-2.78 ; p=0.00)$. In addition, it was also found that burnout partially mediated the relationship between job insecurity and task performance $(\beta=-0.20$, SE $=0.07 ; 99 \% \mathrm{Cl}[-0.41,-0.05])$. There was evident that job insecurity had negative relationship with task performance and burnout had mediating effect on relationship between job insecurity and task performance.
\end{abstract}

\section{Keywords}

burnout, job insecurity, private sector employee, task performance

\section{Pendahuluan}

Iklim persaingan bisnis yang semakin tajam membawa dampak pada dinamika pekerjaan yang semakin dinamis dan tidak menentu. Karyawan di seluruh dunia menghadapi ketidakpastian karena adanya transformasi teknologi, ekonomi, dan perubahan politik (Piccoli et al., 2019). Perubahan ekonomi dan sosial di negara mendesak banyak perusahaan untuk menyusun strategi untuk tetap bertahan diantaranya dengan menerapkan kebijakan downsizing, mergers, dan restrukturisasi (Rudisill et al., 2010) . Hal ini berimpas tergantinya stabilitas dan prediktabilitas oleh ketidakamanan pekerjaan (De Witte et al., 2015). Shoss (2017) memaparkan bahwa ketidakaman pekerjaan berdampak pada berbagai aspek personal maupun organisasi seperti, kesehatan fisik dan mental termasuk didalamnya burnout, sikap kerja, dampak dan perilaku interpersonal yang buruk, perilaku di tempat kerja termasuk didalamnya kinerja, dan perilaku ekstraorganisasional. Menurut Said Iqbal, Presiden Konfederasi Serikat Pekerja Indonesia (KSPI), pada tahun 2017 di Indonesia terjadi pemutusan kerja besar-besaran (Wiwoho, 2018; Septiadi, 2018). Data dari KSPI tersebut juga menunjukan bahwa selama 2017, jumlah pemutusan kerja tersebut meningkat hingga sekitar 80 ribu pemutusan.
Kompetisi global yang semakin memanas dan lingkungan pekerjaan yang tidak pasti mendorong semua organisasi untuk meningkatkan produktivitas dalam bekerja. Produktivitas organisasi merupakan akumulasi dari kinerja individu sehingga hubungan negatif dapat merusakan manfaat dari perubahan organisasi, sedangkan hubungan positif dapat memfasilitasi perubahan (De Cuyper et al., 2020). Studi meta-analisis menunjukkan bahwa terdapat hubungan yang negatif antara kinerja dan ketidakamanan pekerjaan (Shoss, 2017). Dengan demikian, hubungan negatif antara kinerja dan ketidakaman pekerjaan berdampak pada produktivitas organisasi yang menjadi salah satu indikator perubahan organisasi yang mengerakkan organisasi untuk mencapai keunggulan kompetitif dibandingkan organisasi lain. Selain itu, Sverke et al. (2019) memaparkan bahwa karyawan yang mengalami ketidakamanan pekerjaan akan kurang mengerahkan usaha untuk mendukung tujuan organisasi. Penelitian terdahulu menemukan bahwa hubungan antara kinerja karyawan dan ketidakamanan pekerjaan perlu peran mediasi dari

\footnotetext{
${ }^{1,2}$ Fakultas Psikologi Universitas Indonesia

Korespondensi:

Salendu \& Maldini, Fakultas Psikologi, Universitas Indonesia, Depok, 16424, Indonesia

Email: alice.salendu@gmail.com, fachrimaldini@gmail.com
} 
identifikasi organisasi (Piccoli et al., 2017). Lebih lanjut, penelitian tersebut hanya menemukan mediasi penuh pada hubungan ketidakamanan pekerjaan dan kinerja kontekstual. Sedangkan pada hubungan ketidakamanan pekerjaan dan kinerja tugas yang ditemukan hanyalah mediasi parsial. Hal ini membawa pertanyaan mengenai variabel lain yang dapat memediasi hubungan antara ketidakamanan pekerjaan dan kinerja tugas.

Kinerja pekerjaan merupakan keseluruhan penilaian yang diharapkan oleh organisasi dari sekumpulan perilaku berbeda yang dilakukan seseorang selama periode waktu standar tertentu (Motowidlo \& Kell, 2012). Sverke et al. (2019) memaparkan bahwa dalam penelitian kontemporer, kinerja pekerjaan umumnya dianggap sebagai fenomena yang terdiri dari tige jenis yang berbeda yaitu kinerja tugas, kinerja kontekstual, dan perilaku kerja kontraproduktif. Pada penelitian ini akan berfokus pada kinerja tugas. Kinerja tugas meliputi aktivitas yang secara langsung mengubah bahan mentah menjadi barang dan jasa yang merupakan produk dari organisasi serta aktivitas yang melayani dan mempertahankan inti teknis dengan mengisi kembali pasokan bahan bakunya, mendistribusikan produk jadinya, atau menyediakan fungsi perencanaan, koordinasi, pengawasan, atau pengelolaan tim agar dapat berfungsi secara efektif dan efisien (Motowidlo \& Kell, 2012). Piccoli et al. (2017) mendefinisikan kinerja tugas sebagai tingkah laku pekerja yang berhubungan langsung dengan pokok organisasi, namun mereka juga menambahkan bahwa kinerja tugas bukan merupakan tingkah laku kerja yang sukarela, melainkan hal yang harus dilakukan oleh pekerja untuk organisasi tempat dia bekerja.

Piccoli et al. (2017) mendefinisikan ketidakamanan pekerjaan sebagai suatu keadaan dimana terdapat ketidakpastian akan adanya kemungkinan bagi seseorang untuk kehilangan pekerjaannya di masa depan. Shoss (2017) memaparkan ketidakamanan pekerjaan merupakan ancaman yang dirasakan terhadap keberlangsungan dan stabilitas pekerjaan. Sverke et al. (2010) menerjemahkan ketidakamanan pekerjaan sebagai pengalaman subjektif yang menggambarkan ketidakpastian tentang keberlangsungan pekerjaan di masa depan. Dalam meta-analisisnya, Sverke et al. (2002) membedakan ketidakamanan pekerjaan dan kehilangan pekerjaan. Perbedaan antara keduanya terletak pada pengalaman yang dialami oleh individu. Pada ketidakamanan pekerjaan, pengalaman yang dialami merupakan ketidakpastian mengenai masa depan yang dirasakan seseorang di setiap harinya. Sedangkan, pada kehilangan pekerjaan, pengalaman yang dialami dirasakan secara langsung, yaitu pada saat individu kehilangan pekerjaannya. Salah satu dampak dari ketidakamanan pekerjaan yaitu pada aspek kesehatan individu sehingga memungkinkan karyawan terpapar burnout (Sverke et al., 2002).

Burnout merupakan permasalahan kesehatan mental yang paling sering didiskusikan ditengah berbagai tantangan sosial ekonomi. Hal ini menyebabkan individu mengalami peningkatan tekanan dalam kehidupan seharihari khususnya di tempat kerja sehingga menyebabkan timbulnya stres yang berkaitan dengan pekerjaan, kelelahan fisik dan mental yang merupakan gejala-gejala utama dari burnout (Heinemann \& Heinemann, 2017). Maslach \& Leiter (2016) memaparkan bahwa burnout merupakan sindrom psikologis yang muncul sebagai respon berkepanjangan terhadap penyebab stres interpersonal yang kronis di tempat kerja. Terdapat tiga dimensi dari burnout yaitu kelelahan yang berlebihan (exhaustion), perasaan sinisme (cynicism), dan keterpisahan dari pekerjaan (detachment from the job) dimana model ini menempatkan pengalaman stres individu dalam konteks sosial dan melibatkan pemahaman baik tentang diri sendiri dan orang lain (Maslach \& Leiter, 2016). Lebih lanjut, ditemukan hubungan negatif antara kinerja tugas dan emotional exhaustion (Demerouti et al., 2014; Pan, 2017). Selain itu, ditemukan pula bahwa ketidakamanan pekerjaan memiliki hubungan yang positif dengan burnout (Aybas et al., 2015; Blom et al., 2015) dan emotional exhaustion (Piccoli \& De Witte, 2015).

Hubungan negatif antara ketidakamanan pekerjaan dan kinerja karyawan dapat juga dijelaskan oleh teori stres, teori identitas sosial dan teori kontrak psikologis (Sverke et al., 2019). Berdasarkan teori stres, individu yang mengalami stres dan ketidakpastian akan masa depan pekerjaannya akan mengakibatkan penurunan kinerja (Reisel et al., 2010). Karyawan yang merasa bahwa organisasi telah melanggar kontrak psikologis, sebagai akibat dari persepsi ketidakamanan pekerjaan yang dirasakan akan lebih rentan mengalami kelelahan emosional dan cenderung tidak mengerahkan diri untuk organisasi (Piccoli \& De Witte, 2015). Sedangkan berdasarkan teori identitas sosial memaparkan bahwa pengalaman kehilangan pekerjaan potensial dapat mengikis identitas individu terkait pekerjaan (Selenko et al., 2017). Namun demikian, individu yang mengalami ketidakamanan pekerjaan dapat juga menghadapi ancaman terhadap pekerjaan mereka dengan bekerja keras untuk menunjukkan mereka layak untuk dipertahankan organisasi dengan menghasilkan kinerja tugas yang lebih tinggi (Sverke et al., 2019). Lebih lanjut, ketidakaman pekerjaan menyebabkan stres memicu reaksi ketegangan karena mereka harus mengeluarkan sumber daya fisik dan emosional untuk mengantisipasi kehilangan pekerjaannya Piccoli et al. (2017). Berkurangnya sumber daya fisik dan emosional dalam pekerjaan pada seseorang ini berkaitan dengan dimensi utama dari burnout yaitu emotional exhaustion. Dari pemaparan di atas, dapat mengindikasikan bahwa bila seseorang secara terus menerus menilai bahwa dirinya tidak mampu untuk mengatasi ancaman ketidakamanan pekerjaan karena dia tidak memiliki sumber daya yang cukup, maka pada akhirnya salah satu respon yang bisa muncul dari perasaan tersebut adalah burnout.

Penelitian terdahulu, Blom et al. (2015) mengaitkan hubungan antara ketidakamanan pekerjaan dan burnout yang dimoderatori oleh kinerja. Pada penelitian ini akan mengeksplorasi lebih lanjut dinamika hubungan antara kinerja tugas dan ketidakamanan pekerjaan melalui peran moderasi burnout. Hasil penelitian ini dapat berkontribusi 
dalam pengembangan teori kinerja tugas, ketidakamanan pekerjaan, dan burnout pada sektor swasta di Indonesia. Oleh karena itu, berdasarkan latar belakang tersebut, peneliti mengajukan hipotesis, yaitu: (1) ketidakamanan pekerjaan memiliki hubungan yang negatif terhadap kinerja tugas dan (2) burnout dapat memediasi hubungan antara ketidakamanan pekerjaan dan kinerja tugas.

\section{Metode}

Penelitian ini merupakan penelitian korelasional dengan desain non-experimental. Teknik pengambilan sampel yang digunakan untuk penelitian ini adalah non-random atau non-probability sampling dengan jenis convenience sampling. Responden penelitian ini adalah karyawan di sektor swasta dengan usia minimal 21 tahun dan sudah bekerja minimal satu tahun. Pertimbangan pemilihan kriteria pengalaman kerja minimal satu tahun untuk memastikan responden telah memahami dinamika pekerjaan sehingga lebih relevan ketika menjawab kuesioner yang diajukan. Terdapat tiga variabel penelitian yaitu, kinerja tugas sebagai variabel tergantung, ketidakamanan pekerjaan sebagai variabel bebas, dan burnout sebagai variabel mediator.

Data yang diperoleh dalam penelitian ini diambil dengan menggunakan beberapa instrumen self-report berupa kuesioner yang disebarkan kepada partisipan secara daring. Sebelum digunakan untuk mengumpulkan data, penulis melakukan adaptasi alat ukur semua variabel penelitian ke dalam Bahasa Indonesia dengan melakukan back-translate dan kemudian dilakukan penilaian dan pengujian validitas eksternal oleh expert untuk menilai apakah hasil backtranslate tersebut sudah sesuai dengan konteks penelitan. Lebih lanjut, peneliti melakukan studi pendahuluan pada 30 responden untuk menguji adaptasi alat ukut ini.

Instrumen yang digunakan untuk mengukur kinerja tugas adalah alat ukur Task Performance Scale yang dikembangkan oleh (Chirumbolo \& Areni, 2010). Alat ukur ini mengukur kinerja tugas secara unidimensional. Task Performance Scale memiliki 12 item dengan enam skala likert yaitu 1 "Sangat Buruk" sampai 6 "Sangat Baik". Nilai Koefisien intrumen diperoleh $\alpha$ sebesar 0.9 dengan nilai item total correlation setiap item diatas 0.2 . Instrumen yang digunakan untuk mengukur variabel ketidakamanan pekerjaan adalah alat ukur Job Insecurity Scale yang dikembangkan oleh (Sverke et al., 2004). Alat ukur ini mengukur ketidakamanan pekerjaan secara global atau unidimensional, yang terdiri dari 6 item, dengan enam skala likert, yaitu 1 "Sangat Tidak Setuju" hingga 6 "Sangat Setuju". Koefisien konsistensi internal alat ukur tersebut sebesar $\alpha=0.7$ dengan nilai item total correlation pada setiap item diatas 0.2 .

Instrumen yang digunakan untuk variabel burnout adalah Maslach Burnout Inventory - General Scale yang dikembangkan (Maslach et al., 1996). MBI-GS mengukur tingkat burnout seseorang pada berbagai bidang pekerjaan, terdiri dari 16 item yang mengukur tiga dimensi, yaitu emotional exhaustion, depersonalization (cynicism), dan professional efficacy. Terdapat tujuh pilihan jawaban berupa skala likert mulai dari 0 "Tidak Pernah" hingga 6 "Setiap hari". Koefisien Alpha yang diperoleh pada alat ukur ini adalah $\alpha=0.86$ namun karena pada item nomor 13 nilai item total correlation yang diperoleh dibawah 0.2 maka item tersebut dieliminasi. Konsistensi internal interumen tersebut diperoleh koefisien $\alpha$ sebesar 0.87 . Keputusan untuk mengeliminasi item nomor 13 dari alat ukur burnout ini juga didasari oleh penelitian sebelumnya yang memvalidasi alat ukur burnout (Schutte et al., 2000). Pada penelitian tersebut item nomor 13 dieliminasi untuk pengujian reliabilitas karena item tersebut tidak cukup baik untuk menguji dimensi cynicism.

Sebelum melakukan pengujian hipotesis, penulis melakukan uji keterbacaan dan uji coba kepada beberapa orang yang sesuai dengan kriteria partisipan yang telah ditentukan. Setelah alat ukur layak digunakan, pengambilan data dilakukan secara daring dan dilakukan pengolahan data. Teknik analisis statistik yang digunakan adalah analisis deskriptif, analisis korelasi, dan analisis regresi berganda. Selain menggunakan SPSS versi 23.0, penulis juga mengintegrasikan plugin PROCESS MACRO yang dikembangkan oleh Andrew Hayes pada SPSS untuk mengetahui efek mediator pada hubungan antara variabel-variabel yang diukur.

\section{Hasil}

Jumlah partisipan yang didapatkan adalah 108 responden. Namun, data yang diolah hanyalah 106, karena ada satu partisipan yang mengisi kuesioner sebanyak dua kali dan ada satu partisipan yang terindikasi diisi secara asal karena memiliki pola tertentu. Persebaran data demografi responden penelitian tersaji pada Tabel 1 .

Jenis kelamin responden paling banyak muncul dari jenis kelamin perempuan, yaitu $60.4 \%$ berjenis kelamin perempuan dan $39.6 \%$ berjenis kelamin laki-laki. Usia partisipan yang paling mendominasi berasal dari usia 21 sampai 25 tahun, yaitu $56.6 \%$ dari keseluruhan partisipan yang berada pada rentang usia tersebut. Status kerja partisipan kurang lebih memiliki frekuensi yang sama dimana partisipan dengan status kerja kontrak berjumlah 47.2\% dan partisipan dengan status kerja tetap berjumlah $52.8 \%$. Lama bekerja partisipan di dalam satu perusahaan tempat dia bekerja saat ini didominasi oleh partisipan yang bekerja selama satu sampai lima tahun, yaitu sebanyak $83 \%$ dari keseluruhan partisipan bekerja pada rentang tahun tersebut. Sedangkan pada tingkat pendidikan atau pendidikan terakhir didominasi oleh partisipan yang memiliki pendidikan terakhir strata satu, yaitu sebanyak 70 atau $66 \%$ dari keseluruhan partisipan.

Berdasarkan pengujian hipotesis menunjukkan bahwa terdapat hubungan langsung yang negatif antara ketidakamanan pekerjaan dan kinerja tugas $(b=-0.35, t=$ $-2.78 ; p=0.00)$. Berdasarkan pengujian ini dapat disimpulkan bahwa hipotesis satu diterima. Berdasarkan tabel 
Tabel 1. Gambaran Demografis Responden Penelitian

\begin{tabular}{lrc}
\hline Data Demografis & Jumlah & Persentase \\
\hline Usia (dalam tahun) & & \\
$21-25$ & 60 & 56.6 \\
$26-30$ & 26 & 24.5 \\
$31-35$ & 9 & 8.5 \\
$36-40$ & 3 & 1.9 \\
$41-45$ & 3 & 2.8 \\
$46-50$ & 6 & 5.7 \\
Jenis Kelamin & & \\
Laki-laki & 42 & 39.6 \\
Perempuan & 64 & 60.4 \\
Lama Bekerja (dalam tahun) & & \\
1 - 5 & 88 & 83.0 \\
6 - 10 & 10 & 9.4 \\
$11-15$ & 5 & 4.7 \\
> 20 & 3 & 2.8 \\
Status Kerja & & \\
Kontrak & 50 & 47.2 \\
Tetap & 56 & 52.8 \\
Pendidikan Terakhir & & \\
SMA sederajat & 19 & 17.9 \\
D3 sederajat & 11 & 10.4 \\
S1 sederajat & 70 & 66.0 \\
S2 & 6 & 5.7 \\
\hline
\end{tabular}

4, dapat diketahui bahwa ketidakamanan pekerjaan memiliki hubungan yang positif dengan burnout $(b=1.06, t=$ $3.95 ; p=0.00)$. Lebih lanjut, hubungan antara burnout dan kinerja tugas ditemukan signifikan dan negatif $(b=$ $-0.19, t=-4.52 ; p=0.00)$.

Peneliti menggunakan bootstrapping pada pengujian signifikansi efek tidak langsung dari burnout. Menggunakan sampel 5000 bootstrapping dengan confidence interval 99\%, efek tidak langsung dari burnout pada hubungan antara ketidakamanan pekerjaan dan kinerja tugas ditemukan signifikan $(\beta=-0.20, S E=$ $0.07 ; 99 \% C I[-0.41,-0.05])$. Oleh karena itu, dapat disimpulkan bahwa hipotesis dua juga diterima. Namun, perlu dicatat bahwa karena direct effect pada hubungan ketidakamanan pekerjaan terhadap kinerja tugas yang ditemukan signifikan, maka mediasi yang dilakukan oleh burnout terhadap hubungan antara ketidakamanan pekerjaan dan kinerja tugas adalah mediasi parsial.

\section{Pembahasan}

Berdasarkan hasil pengujian statistik ditemukan bahwa ketidakamanan pekerjaan memiliki hubungan negatif yang signifikan terhadap kinerja tugas. Hal ini menunjukan bahwa orang dengan tingkat ketidakamanan pekerjaan yang tinggi akan cenderung memiliki kinerja tugas yang rendah. Temuan ini sesuai dengan penelitian sebelumnya yang juga menemukan bahwa ketidakamanan pekerjaan memiliki hubungan yang negatif terhadap kinerja tugas (Piccoli et al., 2017; Shoss, 2017; Staufenbiel \& König, 2010). Perlu ditekankan bahwa hubungan ketidakamanan pekerjaan dengan kinerja tugas dapat juga dipengaruhi oleh efek positif dari ketidakamanan pekerjaan. Staufenbiel \& König (2010) menjelaskan bahwa ketidakamanan pekerjaan sebagai sebuah stresor dapat dibagi lagi menjadi dua bagian, yaitu hindrance stressor dan challenge stressor. Sebagai hindrance stressor, ketidakamanan pekerjaan dapat menurunkan kinerja tugas. Namun, sebagai challenge stressor, ketidakamanan pekerjaan justru dapat meningkatkan kinerja tugas. Staufenbiel \& König (2010) menemukan bahwa pengaruh negatif ketidakamanan pekerjaan terhadap kinerja tugas secara parsial ditekan oleh efek ketidakamanan pekerjaan sebagai challenge stressor. Hal ini menunjukan bahwa koefisien korelasi yang peneliti dapatkan pada hubungan ketidakamanan pekerjaan dan kinerja tugas memiliki kemungkinan dipengaruhi oleh peran ketidakamanan pekerjaan sebagai challenge stressor.

Pada penelitian ini faktor demografis seperti usia, gender, dan status pekerjaan tidak memiliki hubungan dengan ketidakaman pekerjaan. Hal ini juga tercermin dari 90\% responden penelitian yang memiliki ketidakamanan pekerjaan yang rendah. Hal ini juga sejalan dengan hasil penelitian Huang et al. (2012) yang tidak menemukan hubungan yang signifikan antara ketidakamanan pekerjaan dengan usia, gender, dan status pekerjaan pada 491 karyawan serta 146 supervisor di Cina. Selain itu, kinerja tugas diketahui berkorelasi dengan usia responden. Dengan demikian dapat disimpulkan bahwa seiring pertambahan usia semakin baik kinerja tugasnya.

Penelitian terdahulu juga menunjukkan adanya hubungan yang signifikan dan positif antara kinerja pekerjaan dan usia seseorang (Selenko et al., 2017) . Lebih lanjut, burnout diketahui berkorelasi negatif dengan usia dan berkorelasi positif gender responden. Dengan demikian, semakin muda usia seseorang maka semakin rentan terhadap burnout. Namun demikian, penelitian yang dilakukan Blom et al. (2015) menunjukkan terdapat hubungan yang signifikan dan positif antara burnout dengan gender dan usia. Hasil penelitian ini juga menunjukan bahwa burnout dapat memediasi hubungan antara ketidakamanan pekerjaan dan kinerja tugas. Namun, jenis mediasi yang ditemukan adalah mediasi parsial. Hal ini menunjukan bahwa pengaruh ketidakamanan pekerjaan terhadap kinerja tugas bisa melewati variabel penengah, dalam kasus ini yaitu burnout.

Berdasarkan penelitian sebelumnya, stres dalam pekerjaan dapat dipicu apabila seseorang menilai bahwa ketidakamanan pekerjaan tersebut sebagai ancaman dan orang tersebut melihat bahwa dia tidak mempunyai sumber daya yang cukup untuk mengatasi perasaan tidak aman tersebut (Blom et al., 2015). Sejalan dengan pengertian burnout oleh Maslach \& Leiter (2016) yang mengatakan burnout merupakan respon berkepanjangan terhadap stresor emosional dan interpersonal dalam pekerjaan yang kronis, temuan dari penelitian ini membuktikan bahwa sebelum ketidakamanan pekerjaan memberikan efek negatif terhadap kinerja tugas, bila ketidakamanan tersebut terjadi 
Tabel 2. Hasil Regresi dari Mediasi

\begin{tabular}{lccrc}
\hline Jalur efek langsung dan tidak langsung & $\mathrm{b}$ & \multicolumn{1}{c}{$\mathrm{SE}$} & \multicolumn{1}{c}{$t$} & \multicolumn{1}{c}{$p$} \\
\hline $\mathrm{KP} \rightarrow$ Kinerja Tugas & -0.35 & 0.13 & -2.78 & 0.00 \\
$\mathrm{KP} \rightarrow$ Burnout & 1.06 & 0.27 & 3.95 & 0.00 \\
Burnout $\rightarrow$ Kinerja Tugas & -0.19 & 0.42 & -4.52 & 0.00 \\
\hline Hsil Bootstrap untuk efek tidak langsung & $\beta$ & $\mathrm{SE}$ & $\mathrm{LLCl}$ & $\mathrm{ULCl}$ \\
\hline $\mathrm{KP} \rightarrow$ Burnout $\rightarrow$ Kinerja Tugas & -0.20 & 0.07 & -0.41 & -0.05 \\
\hline
\end{tabular}

Catatan: KP = Ketidaknyamanan Pekerjaan

secara terus menerus, maka salah satu respon yang dapat muncul adalah burnout dan pada akhirnya hal ini dapat menyebabkan seseorang mengalami penurunan dalam kinerja tugas.

Lebih lanjut, hubungan antara kinerja tugas dan ketidakamanan pekerjaan yang dimediasi oleh burnout sejalan pula dengan teori kontrak psikologis dimana ketidakamanan pekerjaan dapat memicu keleahan emosional yang merupakan salah satu ciri dari burnout sehingga berdampak pula pada penurunan kinerja tugas (Piccoli \& De Witte, 2015) .

Meskipun demikian, mediasi yang ditemukan pada penelitian ini adalah mediasi parsial. Hal ini karena walaupun ditemukan indirect effect ketidakamanan pekerjaan terhadap kinerja tugas lewat burnout, dari penelitian masih ditemukan direct effect dari ketidakamanan pekerjaan terhadap kinerja tugas. Lebih lanjut, hal ini mengindikasikan bahwa pengaruh negatif langsung dari ketidakamanan pekerjaan pada kinerja tugas berkurang karena kehadiran burnout sebagai variabel mediator. Burnout yang dirasakan responden berperan sebagai challenge stressor yang menekan efek negatif ketidakamanan pekerjaan dan mendorong responden untuk bekerja lebih keras untuk menunjukkan bahwa mereka layak dipertahankan organisasi yang mempengaruhi kinerja tugas individu (Staufenbiel \& König, 2010; Sverke et al., 2019).Temuan ini menunjukan bahwa terdapat kemungkinan bahwa burnout bukanlah satu-satunya respon yang dapat muncul ketika seseorang merasakan ketidakamanan dalam pekerjaan secara terus menerus.

Faktor lain bisa saja menjadi alasan mengapa ketidakamanan pekerjaan dapat menurunkan kinerja tugas seseorang. Shoss (2017) memaparkan beberapa variabel yang dapat dipertimbangkan untuk menjelaskan hubungan ketidakaman pekerjaan dengan kinerja melalui peran mediasi yaitu mengaitkan ketidakadilan organisasi (organizational injustice), motivasi mempertahanakan pekerjaan (job preservation motivation), dan koping proaktif (proactive coping).

Pada penelitian Piccoli et al. (2019) menjabarkan peran mediasi sikap kerja berupa kepuasan kerja dan komitmen afektif dalam menjelaskan hubungan ketidakaman pekerjaan dan kinerja tugas. Lebih lanjut, penelitian ini memiliki beberapa keterbatasan diantaranya populasi sampel yang sangat heterogen, persebaran demografi partisipan penelitian yang kurang beragam dan sumber data kinerja yang bersifat subjektif. Hal ini dapat menjadi peluang untuk mengembangkan penelitian selanjutnya dengan lebih komprehensif.

\section{Simpulan}

Berdasarkan hasil penelitian, dapat disimpulkan bahwa ketidakamanan pekerjaan memiliki hubungan yang negatif terhadap kinerja tugas dan burnout juga ditemukan dapat memediasi hubungan tersebut. Namun, mediasi yang ditemukan pada penelitian ini adalah mediasi parsial sehingga masih ada variabel lain yang berhubungan dengan ketidakamanan pekerjaan namun juga dapat mempengaruhi penurunan kinerja tugas. Oleh karena itu, penelitian ini dapat menjadi salah satu rujukan untuk mengembangkan penelitian antara ketidakamanan pekerjaan dan kinerja tugas dengan mengeksplorasi variabel lain yang memengaruhi mekanisme hubungan dua variabel tersebut.

Terkait keterbatasan dan kekurangan yang ada pada penelitian ini, peneliti ingin menyarankan beberapa hal yang mungkin dapat diterapkan dalam penelitian selanjutnya, yaitu: (a) pengambilan data mengerucut pada satu bidang pekerjaan khususnya yang rentan dengan ketidakamanan pekerjaan, (b) menggunakan random sampling dalam pencarian partisipan, (c) mencari partisipan dengan persebaran usia yang lebih merata, (d) menggunakan tipe pengambilan data kinerja tugas yang objective-rated, serta (e) melakukan penelitian longitudinal agar tidak terbatas dalam mengambil hubungan kausal.

\section{Referensi}

Aybas, M., Elmas, S., \& Dündar, G. (2015). Job insecurity and burnout: The moderating role of employability. European Journal of Business and Management, 7(9), 195-203.

Blom, V., Richter, A., Hallsten, L., \& Svedberg, P. (2015). The associations between job insecurity, depressive symptoms and burnout: The role of performance-based self-esteem. Economic and Industrial Democracy, 39(1), 48-63. https: //doi.org/10.1177/0143831X15609118

Chirumbolo, A., \& Areni, A. (2010). Job insecurity influence on job performance and mental health: Testing the moderating effect of the need for closure. Economic 
and Industrial Democracy, 31(2). https://doi.org/10.1177/ 0143831 X09358368

De Cuyper, N., Schreurs, B., De Witte, H., \& Selenko, E. (2020). Impact of job insecurity on job performance introduction. Career Development International, 25(3), 221-228. https: //doi.org/10.1108/CDI-06-2020-332

De Witte, H., Vander Elst, T., \& De Cuyper, N. (2015). Job insecurity, health and well-being. In Sustainable working lives: Managing work transitions and health throughout the life course (pp. 109-128). https://doi.org/10.1007/978-94017-9798-6

Demerouti, E., Bakker, A. B., \& Leiter, M. (2014). Burnout and job performance: The moderating role of selection, optimization, and compensation strategies. Journal of Occupational Health Psychology, 19(1), 96-107 https://doi. org/10.1037/a0035062

Heinemann, L. V., \& Heinemann, T. (2017). Burnout research: Emergence and scientific investigation of a contested diagnosis. SAGE Open, 7(1). https: //doi.org/10.1177/2158244017697154

Huang, G.-H., Niu, X., Lee, C., \& Ashford, S. J. (2012). Differentiating cognitive and affective job insecurity: Antecedents and outcomes. Journal of Organizational Behavior, 33(6), 752-769. https://doi.org/10.1002/job.1815

Maslach, C., \& Leiter, M. P. (2016). Understanding the burnout experience: Recent research and its implications for psychiatry. World Psychiatry, 15(2), 103-111. https://doi. org/10.1002/wps.20311

Maslach, C., Jackson, S.E., \& Leiter, M. P. (1996). Maslach Burnout Inventory.(3rd ed). Palo Alto, CA: Consulting Psychologists Press.

Motowidlo, S. J., \& Kell, H. (2012). Job Performance. In I. Weiner, N. Schmitt, \& S. Highhouse (Eds.), Handbook of Psychology: Industrial \& Organizational Psychology (2nd ed., pp. 82-103). https://doi.org/10.1002/9781118133880. hop 212005

Pan, G. (2017). The Effects of Burnout on Task Performance and Turnover Intention of New Generation of Skilled Workers. Journal of Human Resource and Sustainability Studies, 5(3), 156-166. https://doi.org/10.4236/jhrss.2017.53015

Piccoli, B., Callea, A., Urbini, F., Chirumbolo, A., Ingusci, E., \& De Witte, H. (2017).ob insecurity and performance: the mediating role of organizational identification. Personnel Review,46(8),1508-1522. https://doi.org/10.1108/PR-052016-0120

Piccoli, B., \& De Witte, H. (2015). Job insecurity and emotional exhaustion: Testing psychological contract breach versus distributive injustice as indicators of lack of reciprocity. Work and Stress, 29 (3), 246-263. https://doi.org/10.1080/ 02678373.2015.1075624

Piccoli, B., Reisel, W. D., \& De Witte, H. (2019). Understanding the Relationship Between Job Insecurity and Performance: Hindrance or Challenge Effect?. Journal of Career Development , 1-16. https://doi.org/10.1177/0894845319833189
Reisel, W., Probst, T., Chia, S. L., Maloles, C., \& König, C. (2010). The effects of job insecurity on job satisfaction, organizational citizenship behavior, deviant behavior, and negative emotions of employees. International Studies of Management and Organization, 40 (1), 74-91.

Rudisill, J. R., Edwards, J. M., Hershberger, P. J., Jadwin, J. E., \& McKee, J. M. (2010). Coping with Job Transitions over the Work Life. In Handbook of Stressful Transitions Across the Lifespan. https://doi.org/10.1007/978-1-4419-0748-6_6

. Schutte, N., S. Toppinnen, R. K., \& Schaufeli, W.B. (2000) . The factorial validity of the Maslach Burnout Inventory-General Survey across occupational groups and nations. Journal of Occupational and Organizational Psychology 73, 53-66.

Selenko, E., Mäkikangas, A., Mauno, S., \& Kinnunen, U. (2013). How does job insecurity relate to self-reported job performance? Analysing curvilinear associations in a longitudinal sample. Journal of Occupational and Organizational Psychology, 86(4), 522-542.

Selenko, E., Mäkikangas, A., \& Stride, C. B. (2017). Does job insecurity threaten who you are? Introducing a social identity perspective to explain well-being and performance consequences of job insecurity. Journal of Organizational Behavior, 38(6), 856-875. https://doi.org/10.1002/job.2172

Septiadi, A. (2018). KSPI Meragukan Data PHK Kemnaker. Diakses melalui https://nasional.kontan.co.id/news/ kspi-meragukan-data-phk-kemnaker

Shoss, M. K. (2017). Job Insecurity: An Integrative Review and Agenda for Future Research. Journal of Management, 43(6), 1911-1939. https://doi.org/10.1177/0149206317691574

Staufenbiel, T., \& König, C. J. (2010). A model for the effects of job insecurity on performance, turnover intention, and absenteeism. Journal of Occupational and Organizational Psychology, 83(1), 101-117.

Sverke, M., de Witte, H., Näswall, K., \& Hellgren, J. (2010). European perspectives on job insecurity: Editorial introduction. Economic and Industrial Democracy, 31(2), 175-178. https://doi.org/10.1177/0143831X10365601

Sverke, M., Hellgren, J., \& Näswall, K. (2002). No security: A meta-analysis and review of job insecurity and its consequences. Journal of Occupational Health Psychology, 7(3), 242-264. https://doi.org/10.1037/1076-8998.7.3.242

Sverke, M., Hellgren, J., Näswall, K., Chirumbolo, A., De Witte, H., \& Goslinga, S. (2004). Job Insecurity and Union Membership: European unions in the Wake of Flexible Production.P.I.E. - Peter Lang.

Sverke, M., Låstad, L., Hellgren, J., Richter, A., \& Näswall, K. (2019). A meta-analysis of job insecurity and employee performance. International Journal of Environmental Research and Public Health, 16(14), 1-29 https://doi.org/10.3390/ ijerph16142536

Wiwoho, B. (2018). KSPI Perkirakan Gelombang PHK Ritel Masih Terjadi di 2018. Diakses melalui https://www.cnnindonesia.com/ekonomi/20180101153916532-265922/kspi-perkirakan-gelombang-phk-ritel-masihterjadi-di-2018 